\title{
Farklı Nem İçeriklerindeki Siyez Buğdayı Tohumlarının Karbondioksit Değişimleri ve Bazı Mekanik Özelliklerinin Belirlenmesi
}

\author{
Hakan Kibar \\ Bolu Abant İzzet Baysal Üniversitesi, Ziraat ve Doğa Bilimleri Fakültesi, Tohum Bilimi ve Teknolojisi Bölümü, Bolu
}

Geliş tarihi (Received): 08.11.2018 Kabul tarihi (Accepted): 12.12.2018

\section{Anahtar kelimeler: \\ Einkorn siyez buğdayı, karbondioksit değişimi, solunum hızı, nem içeriği}

*Sorumlu yazar

hakan.kibar@ibu.edu.tr
Özet. Bu çalışmada; farklı nem içeriklerindeki $(\% 5,10.5,15,20,25)$ kavuzlu siyez buğdayı tohumlarında (Triticum monococcum L.) karbondioksit $\left(\mathrm{CO}_{2}\right)$ solunum hızında meydana gelen değişimler ve bazı mekanik özellikler araştırılmıştır. Tohumlar $10{ }^{\circ} \mathrm{C}^{\prime}$ de 3 ay süreyle sıcaklık ve nem test kabininde depolanmıştır. Bu süre sonunda $\mathrm{CO}_{2}$ değişimi \%5, 10.5 ve 15 nem içeriklerinde 120 saat, \%20 ve 25 nem içeriklerinde sırasıyla 26 ve 29 saat süreyle ölçüm yapılmıştır. Araştırmanın sonucunda \%5, 10.5, 15, 20 ve 25 nem içeriklerindeki $\mathrm{CO}_{2}$ düzeyleri sırasıyla 504-555, 510-578, 568-1074, 762-9999 ve 1500-9999 ppm olarak tespit edilmiştir. Minimum $\mathrm{CO}_{2}$ solunum hızı 120 . saatte $\% 5$ ve 10.5 nem içeriğinde 0.06 $\mathrm{mgCO}_{2} \mathrm{~kg}^{-1} \mathrm{~h}^{-1}$ olarak belirlenmiştir. Maksimum $\mathrm{CO}_{2}$ solunum hızı ise \%25 nem içeriğinde 1 . saatte $18.09 \mathrm{mgCO}_{2} \mathrm{~kg}^{-1} \mathrm{~h}^{-1}$ olarak tespit edilmiştir. Artan nem içeriğine bağlı olarak mühendislik özelliklerin artış gösterdiği belirlenmiştir. Elde edilen sonuçlara bağlı olarak tohumların yüksek nem içeriğinde bozulması hızlanarak depo iç ortamının çevresel koşulları (sıcaklık ve bağıl nem) olumsuz olarak etkilenebilecektir. Farklı nem içeriklerine sahip tohumlarda daha düşük solunum hızları \%5 nem içeriğinde belirlenmiştir. Ancak depolamada \%5'lik nem düzeyini sağlamak daha fazla soğutma veya havalandırma maliyetine neden olacağından siyez buğdayı tohumlarının \%10.5 nem içeriğinde depolanması tohumların mühendislik özellikleri açısından önerilmektedir.

\section{Determination of Carbon Dioxide Changes and Some Mechanical Properties of Siyez Wheat Seeds in Different Moisture Content}

\author{
Keywords: \\ Einkorn siyez wheat, carbon \\ dioxide change, respiration \\ rate, moisture content
}

\begin{abstract}
The changes in carbon dioxide $\left(\mathrm{CO}_{2}\right)$ respiration rate and some mechanical properties of unhulled siyez wheat (Triticum monococcum L.) in different moisture contents $(5,10.5,15,20,25 \%)$ were investigated in this study. The seeds were storaged in the temperature and moisture test chamber at 10 ${ }^{\circ} \mathrm{C}$ for 3 months. At the end of this period, $\mathrm{CO}_{2}$ changes were measured thourghout 120 hours at $5,10.5$ and $15 \%$ moisture contents and 26 and 29 hours at 20 and $25 \%$ moisture contents. As a result of the study, $\mathrm{CO}_{2}$ levels of 5, 10.5, 15, 20 and 25\% moisture contents were ranged 504-555 ppm, 510-578 ppm, 568-1074 ppm, 762-9999 ppm and 1500-9999 ppm, respectively. Minimum $\mathrm{CO}_{2}$ respiration rate was determined as $0.06 \mathrm{mgCO}_{2} \mathrm{~kg}^{-1} \mathrm{~h}^{-1}$ in 5 and $10.5 \%$ moisture content at $120^{\text {th }}$ hours. The maximum $\mathrm{CO}_{2}$ respiration rate was determined as $18.09 \mathrm{mgCO}_{2} \mathrm{~kg}^{-1} \mathrm{~h}^{-1}$ at $1^{\text {th }}$ hour in $25 \%$ moisture content. It was determined that the some engineering properties increased due to increased moisture content. Depending on the results obtained, the degradation of the seeds will accelerate and the indoor environmental conditions (temperature and relative humidity) in storage may be adversely affected by high moisture contents. The lower respiration rates in seeds with different moisture contents were determined at $5 \%$ moisture content. However, it is determined that the seeds of wheat can be stored in $10.5 \%$ moisture content since storage at $5 \%$ moisture content may cause more cooling or ventilation cost.
\end{abstract}


Kibar, Farklı Nem İçeriklerindeki Siyez Buğdayı Tohumlarının Karbondioksit Değişimleri ve Bazı Mekanik Özelliklerinin Belirlenmesi

\section{GíRiş}

Siyez (Triticum monococcum L.) buğdayı, diploid $(2 n=14)$, kavuzlu primitif bir buğday türüdür. Bu buğday türü ticari olarak üretimi yapılan buğday türlerine göre fitokimyasallar (karotenoidler, tokoferoller, fenolik asitler), protein ve mineral madde miktarları açısından önemli üstünlüklere sahiptir (Hidalgo et al., 2006; 2008).

Çölyak hastalığı, buğday gluteni (gliadinler) ve ona benzer yapı gösteren alkolde çözünebilen bazı arpa ve çavdar proteinlerine (prolaminler) karşı oluşan uygunsuz bağışıklık sistemi tepkilerinin ince bağırsakta düzensizliğe neden olmasıdır (Sollid and Khosla 2005). Günümüzde buğday gluteni ve ona benzer yapı gösteren bazı arpa ve çavdar proteinlerini içeren gıdaları tüketemeyen çölyak hastaları için uygulanan tek tedavi yöntemi ise glutensiz diyet ile beslenmeleridir. Yapılan bazı çalışmalar siyez buğdayının (Triticum monococcum) çölyak hastalığına (gluten intoleransı) sebep olan $\alpha$-gliadin' deki aminoasit dizilimine sahip olduğunu belirtse de (Fasano and Catassi, 2001; Wieser 2001; Vaccino et al., 2009), siyez buğdayının çölyak hastalığına sebep olan toksisiteye çeşide bağlı olarak az neden olduğu veya neden olmadığı yönünde çalışmalar da mevcuttur (De Vincenzi et al., 1996; Pizzuti etal., 2006; Vincentini et al., 2007).

Tohum depolama ortamı, tohum yığınında yer alan biyolojik işlemlerin tohum için faydalı olacağı veya tohum kalitesini etkilemeyeceği şekilde kontrol edilmelidir. Tohum nem içeriği (MC), tohum biyolojik aktivitesini tanımlayan en önemli faktörlerden biridir (Kaleta and Gornicki 2013). Tohumların nemli ortamda kurak koşullara göre daha hızlı bozulduğu bilinmektedir. Kuru koşullarda, bazı tohumlar, iyi bir depolama ortamının sağlanması ile fazla bir kayıp olmadan, 10 yıl veya daha uzun süre depolanabilir. Buna bağlı olarak düşük nemli tohumlar düşük oranda solunum hızına sahip olabilir. Bununla birlikte, nem içeriği yüksek olan tohumlar genellikle daha yoğun $\mathrm{CO}_{2}$ üretim oranlarına neden olan mikrobiyal işlemler için iyi bir ortamdır. Nemli bir ortamda ise tohumlar birkaç ay içinde bünyesindeki enzim aktiviteleri sonucunda canlılıklarını kaybedebilir (Robertson et al., 1939). Tohum bozulması, tohumun kendisinin ve beraberindeki mikroorganizmaların solunması ile ilgilidir. Solunum ise karbondioksit, su buharı ve termal enerji üreten karbonhidrat oksidasyonu (yanma) işlemidir (Kaleta and Gornicki 2013).

Throneberry and Smith (1955), mısırdaki canlılık kaybının solunum oranı ile ilişkili olduğunu bildirmişlerdir. Araştırmacılar tarafından tohumlarda meydana gelen bozulma sürecinin depo ortamındaki sıcaklık ve tohumdaki su aktivitesi ile değişebileceğini, ancak koruma önlemlerinin alınması ve enzim aktivitelerinin kontrol altına alınması ile önlenebileceğini vurgulamıştır (Walters and Engels 1998; McDonald 1999; Murthy et al., 2003; Kibinza et al., 2006).

Taneli ürünler katı, sıvı ve gaz formunu bünyelerinde barındırdıkları için depolama koşulları büyük oranda temel mühendislik özelliklerine bağlıdır. Bu ürünlerin yeterli düzeyde muhafazaları için mühendislik uygulamaları açısından önemli temel mühendislik özelliklerinin arasındaki ilişkilerin bilinmesi gerekir. Bu açıdan tohumlar için önem arz eden bazı temel mühendislik özellikleri nem içeriği, tohum taneleri arasındaki içsel sürtünme ve kayma açısı ile tohum ve depo malzemesi arasındaki statik sürtünme katsayısıdır (Horabik and Molenda 1988).

$\mathrm{Bu}$ çalışmanın amacı, Kastamonu ili İhsangazi ilçesinden toplanan kavuzlu siyez einkorn buğdayı tohumlarının \%5, 10.5, 15, 20 ve 25 nem içeriğinde $\mathrm{CO}_{2}$ seviyesindeki değişime bağlı olarak solunum hızında meydana gelen değişimleri ve bazı mekanik özelliklerini (içsel sürtünme açısı, kayma açısı ve statik sürtünme katsayısı) araştırmaktır.

\section{MATERYAL VE METOT}

Araştırmada materyal olarak Kastamonu ili ìsangazi ilçesinde yaygın olarak yetiştiriciliği yapılan ve 2017 yılı hasat sezonuna ait kavuzlu siyez buğdayı kullanılmıştır.

Siyez buğdayına ilişkin $10 \mathrm{~g}$ örnek 3 tekerrürlü olacak şekilde fırın kapları ile $130{ }^{\circ} \mathrm{C}^{\prime}$ lik fırında 19 saat süre ile tutulmuştur. Bu sürenin sonunda fırından çıkarılan örnekler 30 dakika süre ile desikatörde soğumaya bırakılmıştır. Mühendislik uygulamalarında kuru ağırlığa göre hesaplanan nem içeriği kullanıldığı için doğal nem içeriği aşağıda verilen Eşitlik 1 ve 2 yardımıyla belirlenmiştir (Bakker-Arkema 1999; ASAE 2008).

$$
\begin{aligned}
& M_{w \cdot b}=\left(\frac{W_{w}}{W_{t}}\right) \times 100 \\
& M_{\text {d.b }}=\left(\frac{W_{w . b}}{100-M_{w . b}}\right) \times 100
\end{aligned}
$$

Eşitliklerde;

$M_{w . b}$ : Örneğin yaş ağırlığa göre doğal nem içeriği, (\%)

$\mathrm{W}_{\mathrm{w}}$ : Örneğin içerdiği su miktarı, $\left(\mathrm{W}_{\text {yaş }}-\mathrm{W}_{\text {kuru }}(\mathrm{g})\right.$

$W_{t} \quad$ : Örneğin toplam ağırlığı, (g)

$M_{d . b}$ : Örneğin kuru baza göre doğal nem içeriği, (\%) 
Kibar, Farklı Nem İçeriklerindeki Siyez Buğdayı Tohumlarının Karbondioksit Değişimleri ve Bazı Mekanik Özelliklerinin Belirlenmesi

\begin{tabular}{llll}
\hline Yukarıda verilen eşitlik yardımıyla kavuzlu tohum & $\mathrm{m}$ & : Siyez buğdayı tohum ağırlığı, $(\mathrm{kg})$ \\
örneklerinde başlangıç nemi \%10.5 olarak & $\Delta t$ & : Deney süresi, (h) \\
belirlenmiştir. Çalışmada \%10.5 nem düzeyinin & $V_{m}$ & : Gazın molar hacmi, $\left(\mathrm{L} \mathrm{mol}^{-1}\right)$ \\
üzerinde $\% 15,20$ ve 25 nem düzeyleri de ele alınmıştır. & $\mathrm{R}$ & : Gaz sabiti, $\left(0.08206 \mathrm{~L}^{-1} \mathrm{~mol}^{-1} \mathrm{~K}^{-1}\right)$ \\
Atmosfer koşullarına bağlı olarak depo iç ortamında & $\mathrm{T}$ & : Sıcaklık, (K) \\
havalandırma, ısıtma ve soğutma gibi nedenlerden & $\mathrm{P}$ & : Basınç, (atm)
\end{tabular}

dolayı sıcaklık ve bağıl nem ile meydana gelebilecek herhangi bir olumsuz durum depolanan tohum nem içeriğinde de değişimlere neden olabilecektir. Bu nedenle tohumlara daha yüksek nem düzeyleri uygulanmıştır. \%5 nem düzeyi için kurutma fırınında tohum örnekleri kurutularak tohum nem düzeyi düşürülmüştür. \%10.5 nem düzeyinin üzerindeki \%15, 20 ve 25 nem içerikleri için aşağıda verilen Eşitlik 3 yardımıyla ilave dilecek saf su miktarı hesaplanmış ve tohum örneklerine ilave edilmiştir. Daha sonra farklı nem içerikleri için her bir tohum partisi hava almayacak şekilde polietilen torbalara konulmuş ve bu torbalar 3 ay için sıcaklık ve nemi ayarlanabilen test kabininde 10 ${ }^{\circ} \mathrm{C}$ sıcaklıkta ve \%65 nem içeriğinde depolanmıştır. Bu sürenin sonunda her bir tohum partisinde aşağıdaki deneyler 3 tekerrürlü olarak yapılmıştır.

$Q=\frac{W \times\left(M_{f}-M_{i}\right)}{100-M_{f}}$

Eşitlikte;

Q : ilave edilmesi gereken su miktarı, (g)

W : Tohum örneklerinin ağırlığı, (g)

$\mathrm{M}_{\mathrm{i}} \quad$ : Tohum örneğinin ilk nem içeriği, (\%)

$M_{f} \quad$ : Tohum örneğinin son nem içeriği, (\%)

Farklı nem içeriklerindeki siyez buğdayı örneklerinin içsel sürtünme açılarının belirlenmesinde Zou and Brusewitz (2001), Molenda et al., (2002)' deki esaslar göz önüne alınarak direkt kesme yöntemi kullanıımıştır. Kavuzlu siyez buğdayı tohumlarının içsel sürtünme açılarının hesaplanmasında Eşitlik 6, 7 ve 8 kullanılmıştır.

$\sigma=\frac{\mathrm{N}}{\mathrm{A}} \times 100$

$\tau=\frac{\mathrm{T}}{\mathrm{A}} \times 100$

$\tau=(\mathrm{c}+\sigma x \tan \varphi)$

Eşitliklerde;

$\sigma \quad$ : Normal gerilme, $(\mathrm{kPa})$

$\mathrm{N}$ : Örnek üzerine uygulanan sabit yük, $(\mathrm{kg})$

A : Hücresel alan, $\left(\mathrm{cm}^{2}\right)$

$\tau \quad$ : Kesme gerilmesi, $(\mathrm{kPa})$

$\mathrm{T} \quad$ : Kesme kuvveti, (kg)

c : Kohezyon katsayısı

$\varphi \quad$ : İçsel sürtünme açısı, (derece)

Farklı nem içeriklerindeki kavuzlu siyez buğdayı tohumlarının solunum hızlarının belirlenmesinde hızı bir sonuç sağlayan Testo $535 \mathrm{CO}_{2}$ ölçüm cihazı ile tohumların ortama yaymış olduğu $\mathrm{CO}_{2}$ düzeyi ppm olarak ölçülmüştür. Bu amaçla $1500 \mathrm{~mL}$ hacimli bir kaba yaklaşık $200 \mathrm{~g}$ tohum konulduktan sonra $\mathrm{CO}_{2}$ ölçüm probu kaba yerleştirilmiş ve kabın hava almaması için parafilm ile sıkıca kapatılarak kabın sızdırmazlığı sağlanmıştır. Tohumların yaymış olduğu $\mathrm{CO}_{2}$ miktarı ölçülmüş ve Eşitlik 4 ve 5 yardımıyla farkı nem içeriklerine bağlı olarak solunum değişimleri hesaplanmıştır (Raudiene et al., 2017).

$\mathrm{RR}=\frac{{ }_{\mathrm{C}_{\mathrm{CO}_{2}}} \times \mathrm{M}_{\mathrm{CO}_{2}} \times \mathrm{V}_{\mathrm{h}}}{\mathrm{V}_{\mathrm{m}} \times \mathrm{m} \times \Delta \mathrm{t}}$

$\mathrm{V}_{\mathrm{m}}=\frac{\mathrm{R} \times \mathrm{T}}{\mathrm{P}}$

Eşitliklerde;

RR : $\mathrm{CO}_{2}$ solunum hızı, $\left(\mathrm{mgCO}_{2} \mathrm{~kg}^{-1} \mathrm{~h}^{-1}\right)$

$\Delta_{\mathrm{CO}_{2}}$ : ppm düzeyinde $\mathrm{CO}_{2}$ hacimsel konsantrasyon değişimi, $\left(10^{-6} \mathrm{~L} \mathrm{~L}^{-1}\right)$

$M_{\mathrm{CO}_{2}}: \mathrm{CO}_{2}$ gazının moleküler ağırlığı $\left(44.01 \mathrm{~g} \mathrm{~mol}^{-1}\right)$

$V_{h} \quad:$ Kabın hacmi, (L)

Kavuzlu siyez buğdayı tohumlarının kayma açısı üzerine farklı nem içeriklerinin etkisini belirlemek amacıyla tohum örnekleri $20 \mathrm{~cm}$ 'lik çapa sahip polietilen huni yardımıyla temiz ve pürüzsüz bir yüzeye zeminden yaklaşık $25 \mathrm{~cm}$ yukarıdan boşaltıldıktan sonra dijital eğim açı̈llçer yardımıyla eğim ölçülerek kayma açısı belirlenmiştir.

Siyez buğdayı örneklerinin statik sürtünme katsayıları Beyhan ve ark., (1994)'e göre belirlenmiştir. Yöntemde test yüzeyi olarak galvanize çelik yüzey kullanılmıştır. Deney sırasında test yüzeyi hızı ayarlanabilen doğru akım motoru ile düşük bir hızla hareket ettirilmiş, buna bağlı olarak oluşan sürtünme kuvveti dijital dinamometreden okunmuştur. Tohum örneklerinde statik sürtünme katsayıları Eşitlik 9 yardımıyla hesaplanmıştır.

$\mu_{\mathrm{s}}=\frac{\mathrm{F}_{\mathrm{s}}}{\mathrm{W}}$

Eşitlikte;

$\mu_{S} \quad$ :Statik sürtünme katsayısı,

$\mathrm{F}_{\mathrm{S}} \quad$ : Sürtünme kuvveti, $(\mathrm{N})$

W : Normal kuvvet, $(\mathrm{N})$ 
Kibar, Farklı Nem İçeriklerindeki Siyez Buğdayı Tohumlarının Karbondioksit Değişimleri ve Bazı Mekanik Özelliklerinin Belirlenmesi

Çalışmada elde edilen verilerin
değerlendirilmesinde SPSS 11.0 istatistik paket programı kullanılmıştır. Farklı nem içeriklerinde tekerrürlü olarak elde edilen veriler için varyans analizi uygulanmıştır. Çalışma sonucunda elde edilen ortalama değerler Duncan çoklu karşılaştırma testi ile $\mathrm{P}<0.05$ önem düzeyinde değerlendirilmiştir.

\section{BULGULAR VE TARTIŞMA}

Farklı nem içeriklerine sahip tohum örneklerinde $\mathrm{CO}_{2}$ ölçümleri 120 saat olarak planlanmıştır. Ancak tohum nem içeriğinin yükselmesi nedeni ile tohumun solunum hızı artışına bağlı olarak \%20 ve 25 nem içeriklerinde sırasıyla 29. ve 26. saatte deneyler sonlandırılmıştır. Bunun nedeni, ifade edilen zaman dilimlerinde $\mathrm{CO}_{2}$ konsantrasyonu cihazın maksimum ölçüm değeri olan 9999 ppm düzeyine ulaşılmış olmasıdır.

Çalışma sonucunda farklı nem içeriklerinde elde edilen $\mathrm{CO}_{2}$ miktarları ve bunlara bağlı olarak belirlenmiş $\mathrm{CO}_{2}$ solunum hızları Şekil 1'den Şekil 5'e kadar olan şekillerde verilmiştir. Şekiller incelendiğinde minimum $\mathrm{CO}_{2}$ solunum hızı 120 . saatte $\% 5$ ve 10.5 nem içeriğinde $0.06 \quad \mathrm{mgCO}_{2} \quad \mathrm{~kg}^{-1} \quad \mathrm{~h}^{-1}$ olarak belirlenmiştir. Maksimum $\mathrm{CO}_{2}$ solunum hızı ise \%25 nem içeriğinde 1. saatte $18.09 \mathrm{mgCO}_{2} \mathrm{~kg}^{-1} \mathrm{~h}^{-1}$ olarak tespit edilmiştir.

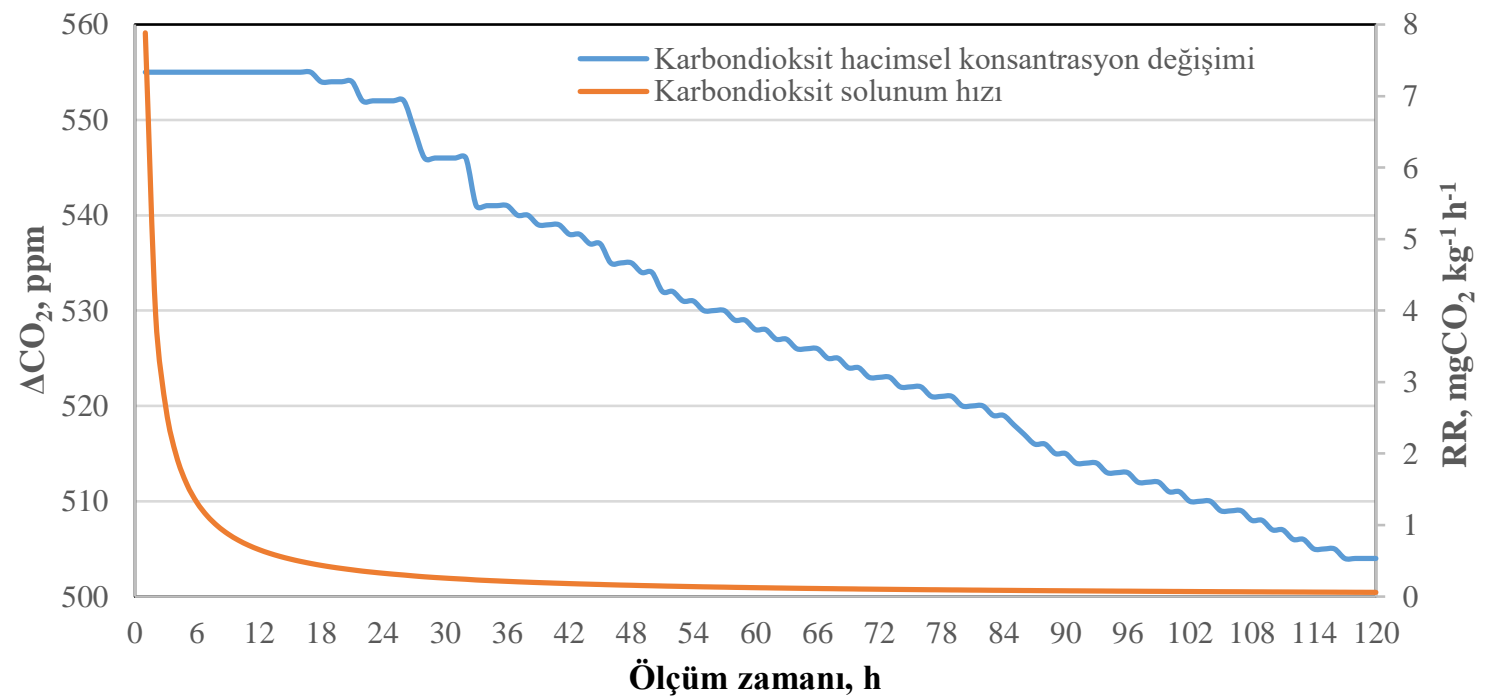

Şekil 1. Zamana bağlı olarak \%5 tohum nem içeriğindeki $\mathrm{CO}_{2}$ hacimsel konsantrasyon değişimi ve $\mathrm{CO}_{2}$ solunum hızı. Figure 1. $\mathrm{CO}_{2}$ volumetric concentration change and $\mathrm{CO}_{2}$ respiration rate at $5 \%$ seed moisture content depending on time.

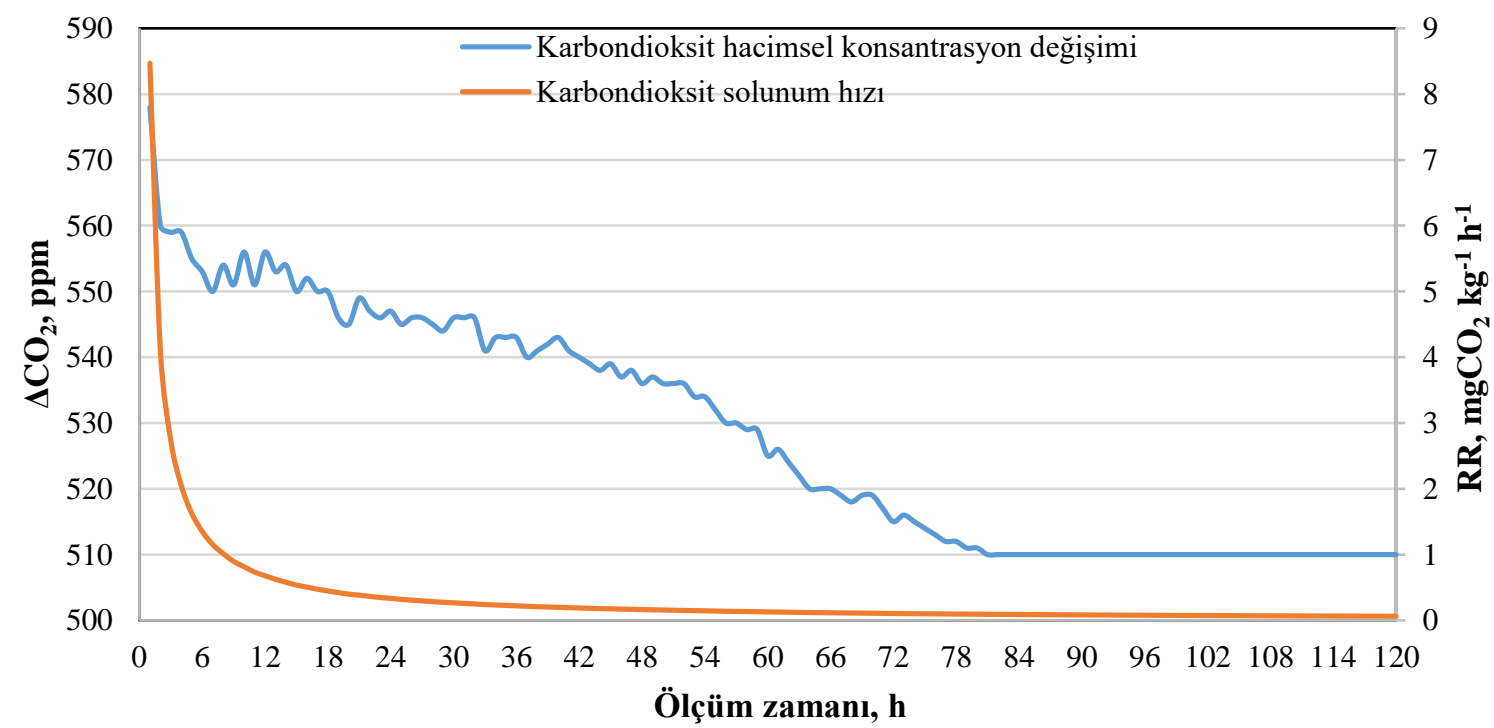

Şekil 2. Zamana bağlı olarak \%10.5 tohum nem içeriğindeki $\mathrm{CO}_{2}$ hacimsel konsantrasyon değişimi ve $\mathrm{CO}_{2}$ solunum hızı. Figure 2. $\mathrm{CO}_{2}$ volumetric concentration change and $\mathrm{CO}_{2}$ respiration rate at $10.5 \%$ seed moisture content depending on time. 
Kibar, Farklı Nem İçeriklerindeki Siyez Buğdayı Tohumlarının Karbondioksit Değişimleri ve Bazı Mekanik Özelliklerinin Belirlenmesi

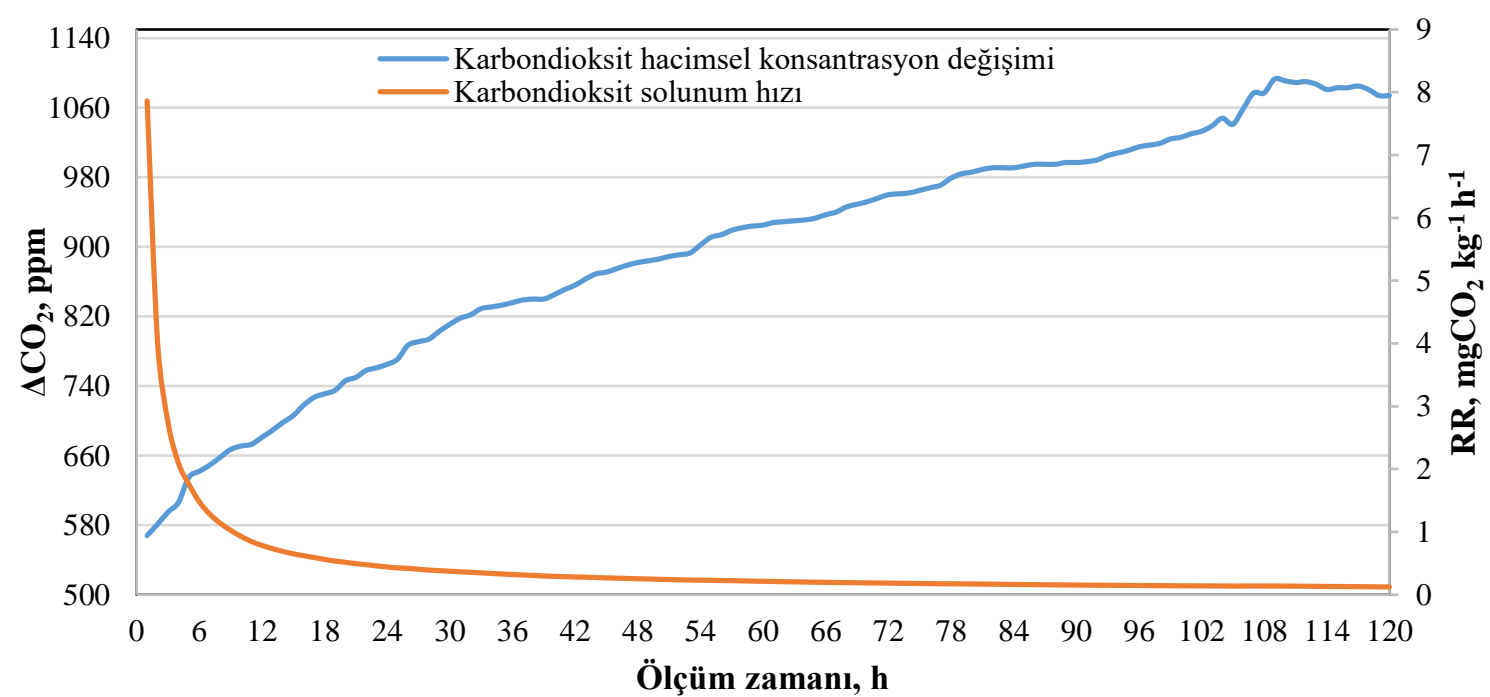

Şekil 3. Zamana bağlı olarak \%15 tohum nem içeriğindeki $\mathrm{CO}_{2}$ hacimsel konsantrasyon değişimi ve $\mathrm{CO}_{2}$ solunum hızı. Figure 3. $\mathrm{CO}_{2}$ volumetric concentration change and $\mathrm{CO}_{2}$ respiration rate at $15 \%$ seed moisture content depending on time.

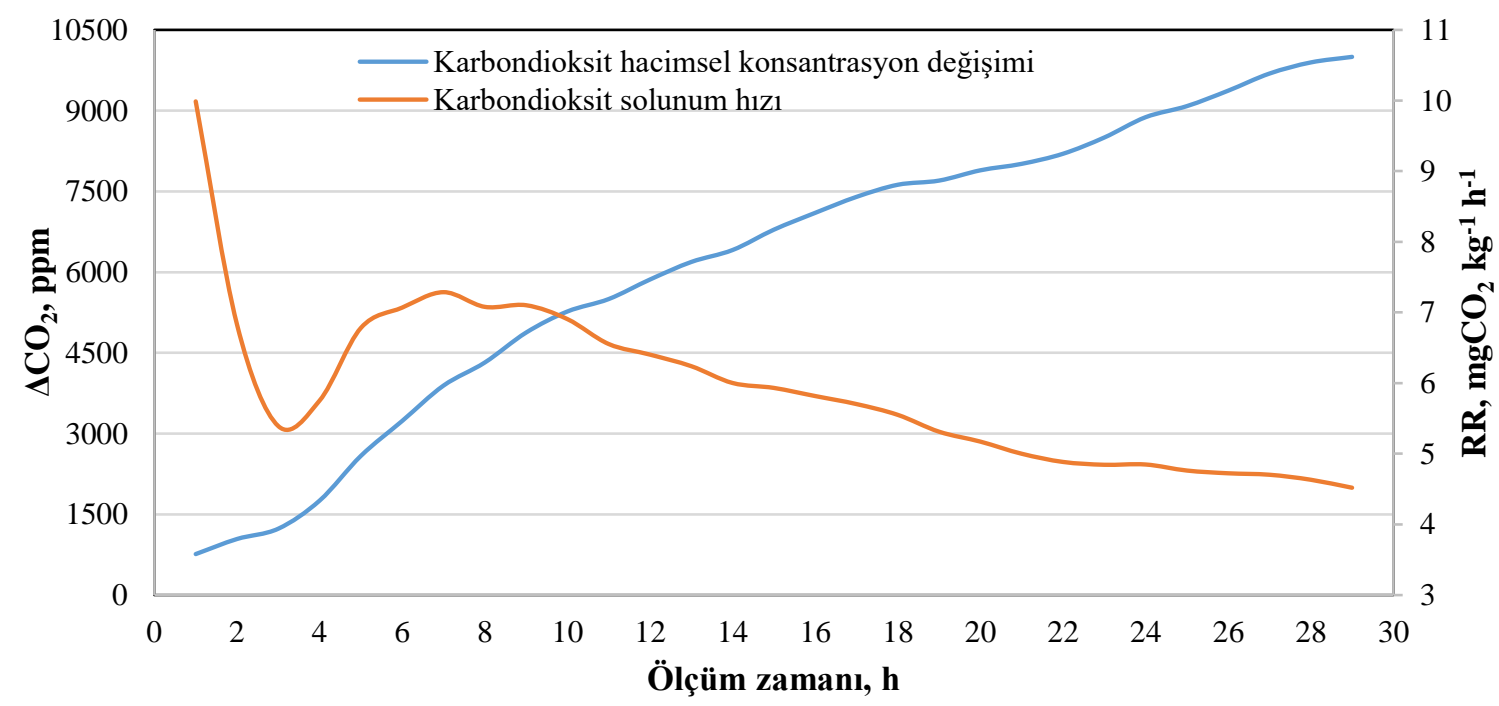

Şekil 4. Zamana bağlı olarak \%20 tohum nem içeriğindeki $\mathrm{CO}_{2}$ hacimsel konsantrasyon değişimi ve $\mathrm{CO}_{2}$ solunum hızı. Figure 4. $\mathrm{CO}_{2}$ volumetric concentration change and $\mathrm{CO}_{2}$ respiration rate at $20 \%$ seed moisture content depending on time.

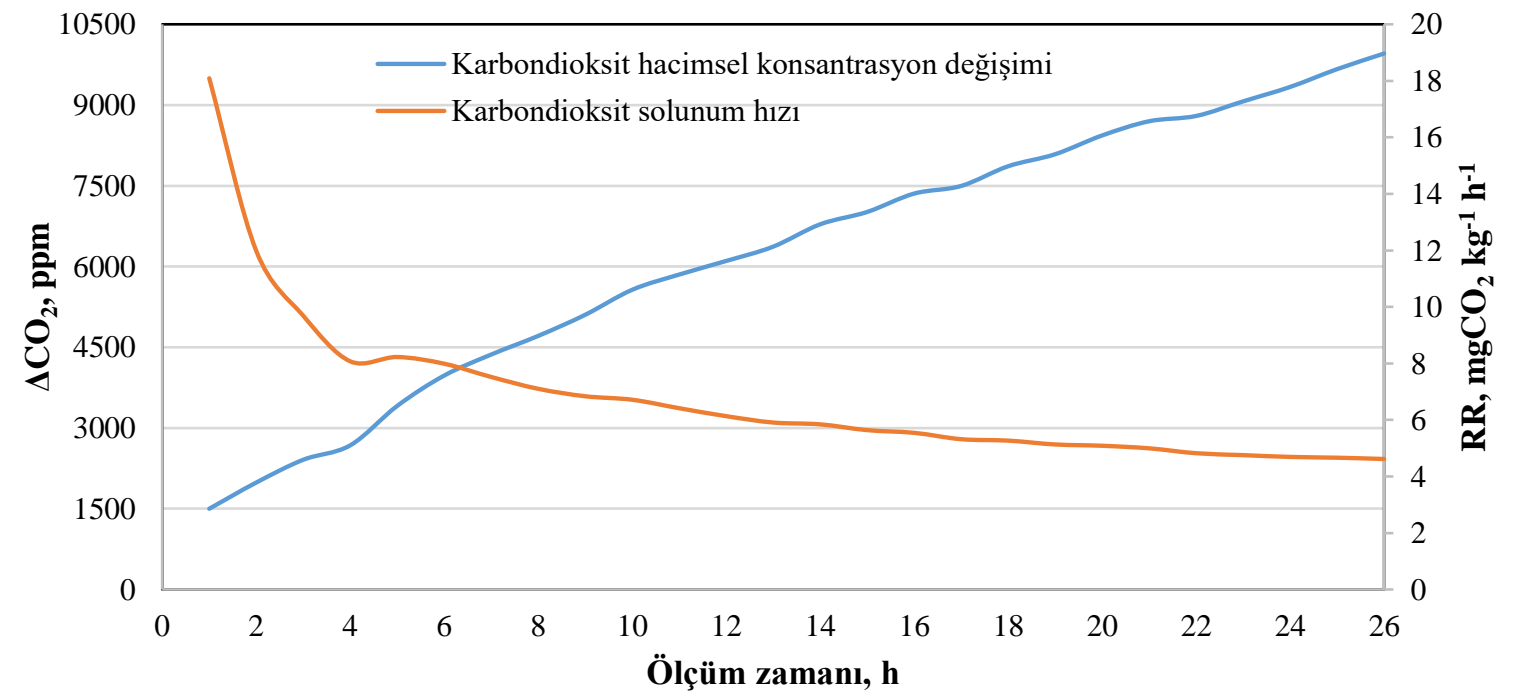

Şekil 5. Zamana bağlı olarak \%25 tohum nem içeriğindeki $\mathrm{CO}_{2}$ hacimsel konsantrasyon değişimi ve $\mathrm{CO}_{2}$ solunum hızı. Figure 5. $\mathrm{CO}_{2}$ volumetric concentration change and $\mathrm{CO}_{2}$ respiration rate at $25 \%$ seed moisture content depending on time. 
Kibar, Farklı Nem İçeriklerindeki Siyez Buğdayı Tohumlarının Karbondioksit Değişimleri ve Bazı Mekanik Özelliklerinin Belirlenmesi

\%5 ve 10.5 nem düzeylerinde ölçülen $\mathrm{CO}_{2}$ miktarları 120 saat süresince azalma eğilimi göstermiştir. Burada tohum nem içeriği artmasına rağmen ölçülen $\mathrm{CO}_{2}$ miktarları azalmış ve buna bağlı olarak da solunum hızları azalmıştır. Solunum hızının artmaması özellikle tohumun depolama süresince bozulmasının önüne geçebilecek en önemli etkenlerden bir tanesidir. Solunumun yavaş olması yine tohum bünyesindeki mekanizmanın yavaş çalışmasına ve besin kalitesinin azalmasının da önüne geçebilmektedir. Diğer bir etken solunumun düşük hızda olması tohumun canlılığını ve çimlenme kabiliyetinin de azalmasını engellemektedir. Çalışmada kullanılan tohum nem içeriklerindeki artışa bağlı solunum hızları azalış göstermiştir. Elde edilen sonuçlara bağlı olarak solunum hızının yüksekliği siyez buğdayının depo ömrünün kısa olacağının da bir göstergesidir. Solunumun artması kuru madde kaybını artırmaktadır. Ayrıca solunum artışı yine tohumun muhafaza edildiği depo ortamının sıcaklığının ve nem düzeyinin artışına neden olmaktadır.

Karaçalı (2009) ve Jian et al. (2014) solunum hızına etkili faktörleri; tohum genetik yapısı, olgunluk durumu, organ ve doku tipi, büyüklüğü ile yüzey/hacim oranı, tohumun mekanik olarak zarar görmesi, tohum nemi, depo ortamının sıcaklığı, bağıl nemi, oksijen konsantrasyonu, mikrobiyal bulaşma, ve tohum tarafından salınan $\mathrm{CO} 2$ miktarı olarak belirtmişlerdir. Dolayısıyla bu çalışmada da etkili koşullardan tohum neminin farklı düzeyleri ele alınmış olup solunum hızı değişimi üzerine etkilerinin olduğu belirlenmiştir.

Er ve Başalma (2014), tohumlarda solunum hızının çok yükselmesi tohumdan değil, ortamda oluşan küf mantarlarından kaynaklandığını belirtmişlerdir. Dolayısıyla depolama ortamı küf mantarlarının oluşmasına imkan vermeyecek düzeyde kalırsa, oluşabilecek kuru madde kayıplarının çok önemli olmadığını ifade etmişlerdir (Magan et al., 2004).

Huang et al. (2013) ve Chidananda et al. (2014) tohum nem içeriğindeki artış ile solunum hızının arttığını saptamışlardır. Bu çalışmada da benzer sonuçlar bulunmuştur.

Kavuzlu siyez tohum örnekleri için farklı nem içeriklerindeki içsel sürtünme açıları, $R^{2}$ ve standart sapma değerleri Şekil $6^{\prime}$ da verilmiştir. Şekil $6^{\prime}$ nın incelenmesiyle de görülebileceği gibi nem içeriği artışı ile içsel sürtünme açısının arttığı saptanmıştır. Bu bağlamda içsel sürtünme açısının en yüksek değeri $\% 25$ nem içeriğinde $\left(\varphi=27.3^{\circ} \pm 0.55\right)$, en düşük değeri ise ise $\% 5$ nem içeriğinde $\left(\varphi=23.5^{\circ} \pm 0.46\right)$ olduğu belirlenmiştir. Tohum örneklerinde \%5-25 nem aralığı ile içsel sürtünme açıları arasında pozitif lineer ilişki belirlenmiş olup bu ilişki Şekil $6^{\prime}$ de verilmiştir. İçsel sürtünme açılarına ilişkin varyans analiz sonuçları incelendiğinde, nem içeriğinin içsel sürtünme açısına $\mathrm{P}<0.01$ olasılık düzeyinde önemli etkisinin olduğu belirlenmiştir.

Molenda et al. (1998), Baryeh (2002), Sahoo and Srivastava (2002), Rusinek and Stasiak (2004), farklı tohum örnekleri üzerinde yapmış oldukları çalışmalarında nem içeriğinin artması ile içsel sürtünme açısının arttığını belirtmişlerdir.

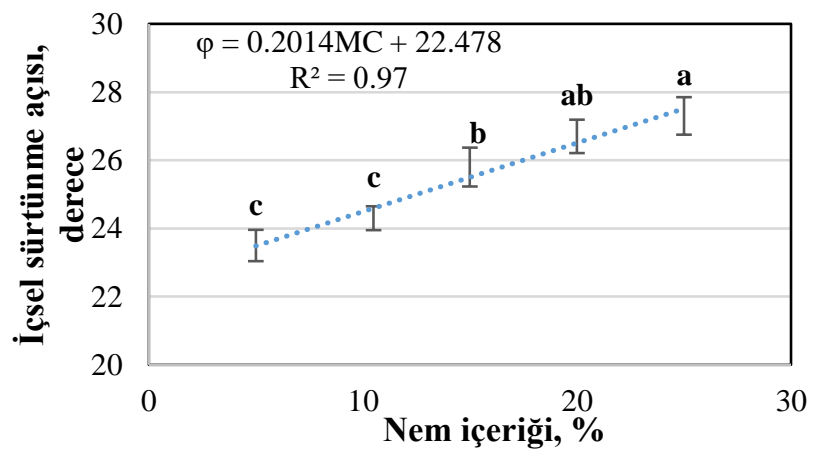

Şekil 6. Farklı nem içeriklerinin içsel sürtünme açısı üzerine etkileri.

Figure 6. Effects on the internal friction angle of different moisture contents.

Farklı nem içeriklerinde siyez buğdayı tohumlarının kayma açıları Şekil 7' de verilmiştir. \%5, 10.5, 15, 20 ve 25 nem içeriklerine bağlı olarak açı değerleri sırasıyla; $19.6^{\circ} \pm 0.40, \quad 20.4^{\circ} \pm 0.42, \quad 22.7^{\circ} \pm 0.59, \quad 23.9^{\circ} \pm 0.45$ ve $24.7^{\circ} \pm 0.85$ olarak belirlenmiştir. Farklı nem içeriklerinin kayma açılarına ait değerler, istatistiki olarak değerlendirildiğinde nem içerikleri arasında önemli farklılıkların olduğu saptanmıştır $(P<0.01)$.

Mahjoub et al. (2014) iki farklı buğday çeşidinde ve \%12, 15 ve 18 nem içeriğinde kayma açısını araştırmışlardır. Kayma açısının en düşük değerini $19.84^{\circ}$, en yüksek değerini ise $24.63^{\circ}$ olarak belirlemişlerdir. Sonuç olarak nem içeriğinin artışı ile kayma açısının arttığını belirtmişlerdir. Bu çalışmada elde edilen veriler, yapılmış olan çalışmayla benzerlik göstermektedir.

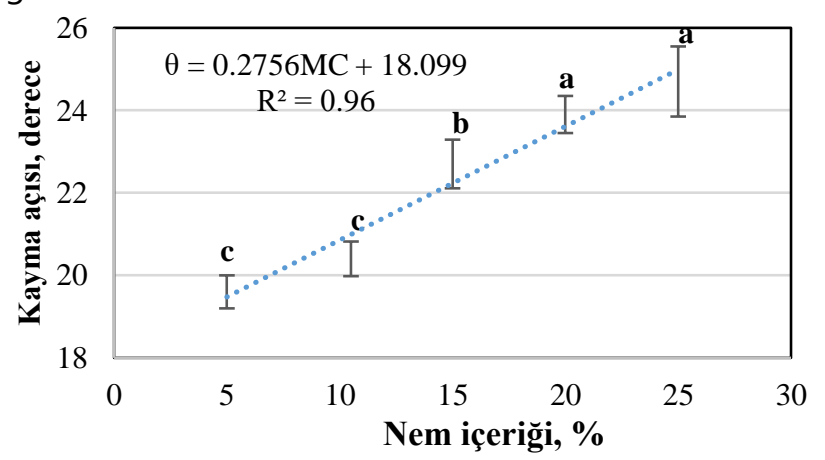

Şekil 7. Farklı nem içeriklerinin kayma açısı üzerine etkileri. Figure 7. Effects on the repose angle of different moisture contents. 
Kibar, Farklı Nem İçeriklerindeki Siyez Buğdayı Tohumlarının Karbondioksit Değişimleri ve Bazı Mekanik Özelliklerinin Belirlenmesi

Nem içeriğine (\%5, 10.5, 15, 20 ve 25$)$ ve yüzeye bağlı (galvanize çelik) olarak belirlenen statik sürtünme katsayıları, $R^{2}$ değerleri ile standart sapmalar Şekil $8^{\prime}$ te verilmiştir. Şekil 8' ten de görülebileceği gibi nem içeriğinin artması ile statik sürtünme katsayısının lineer bir artış meydana getirdiği gözlemlenmiştir. Sürtünme yüzeyinde nem içeriğine bağlı artış, normal kuvvetin (W) neme bağlı artışı ile ilişkilendirilebilir. Tohum nem içeriğinin artması ile statik sürtünme katsayılarındaki en yüksek değerler \%25 nem içeriğinde $0.451 \pm 0.009$ olarak saptanmıştır. Yüzey mutlak pürüzlülük katsayısının galvanize çelik malzemede ise 0.12-0.15 (Kutoğlu 1980) arasında olması bu durum üzerinde önemli derecede etkili olmaktadır. Yapılan istatistiki analiz sonucunda nem içeriklerinin galvanize çelik yüzeyin statik sürtünme katsayısı üzerine $P<0.01$ olasılık düzeyinde önemli etkisinin olduğu saptanmıştır.

Lawton (1980), Beyhan ve ark. (1994), Gupta and Das (1997), Jain and Bal (1997), Baryeh (2002), farklı biyolojik malzemeler üzerinde yapmış oldukları çalışmalarında nem içeriğinin artışı ile statik sürtünme katsayısının farklı test yüzeylerinde arttığını belirlemişlerdir. Bu çalışmada da diğer araştırıcıların sonuçlarına benzer sonuçlar elde edilmiştir.

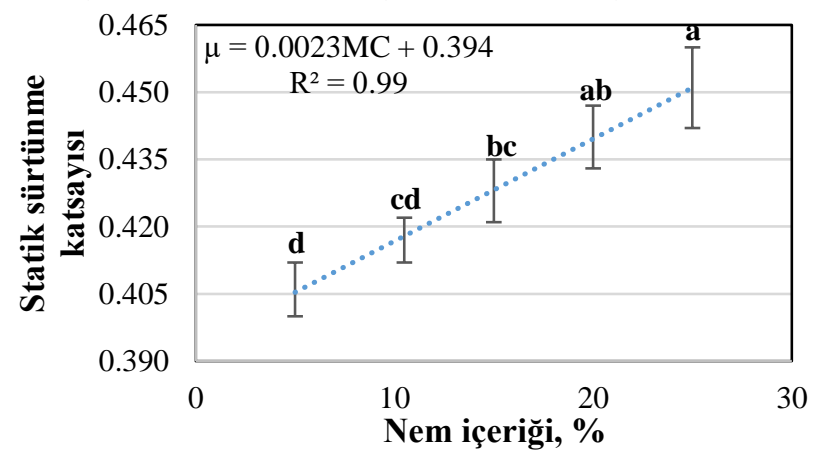

Şekil 8. Farklı nem içeriklerinin statik sürtünme katsayısı üzerine etkileri.

Figure 8. Effects on the static coefficient of friction of different moisture contents.

\section{SONUÇ}

Çalışma sonucunda, kavuzlu siyez buğdayı tohumlarının 3 aylık depolama sonucunda özellikle yüksek nem içeriğinde $\mathrm{CO}_{2}$ solunum hızının arttığı belirlenmiştir. Bu artış tohumun canlılı̆̆ının ve besin kompozisyonunun azalması gibi kayıplara neden olabilmektedir. Nitekim bu çalışmada yüksek neme sahip tohumlarda çimlenmeler gözlemlenmiştir. Nem içeriğinin artmasıyla tohumların bazı mekanik özelliklerinde artış olduğu belirlenmiştir. Meydana gelen artışlar, depolama yapılarının konstrüksiyon malzemesinde daha yüksek basınçlara neden olarak yapısal sorunların ortaya çıkmasına sebep olabilecektir. Bu nedenle, tohumların düşük nem içeriğinde depolanması ve uygun çevre koşullarının sağlanması ile ortaya çıkan depolama kayıpları ve bazı mühendislik özellikleri ile ilgili artışlar önlenebilir. Besin kayıpları ile mühendislik özelliklerinde ortaya çıkan artış oranını en az düzeye indirmek için tohum neminin depolama sırasında \%10 veya daha düşük seviyede tutulması gerekmektedir. Depolama ortamında düşük sıcaklık ve bağıl nem gibi çevresel koşulların sağlanabilmesi için uygun hızda yeterli miktarda havalandırma ile soğutma veya ısıtma yapılması gerekmektedir.

\section{KAYNAKLAR}

ASAE 2008. ASAE S352.2 APR1988 (R2008), Moisture Measurement - Unground Grain and Seeds. USA.

Bakker-Arkema FW., 1999. Grains and grain quality. CIGR Handbook of Agricultural Engineering, Agro-processing Engineering, Vol. IV (Eds. Bakker-Arkema FW., De Baerdemaeker J., Amirante P., Ruiz-Altisent $M$ and Studman (J), American Society of Agricultural Engineers, St. Joseph, Michigan, USA, pp. 1-11.

Baryeh EA., 2002. Physical properties of millet. Journal of Food Engineering, 51(1): 39-46.

Beyhan MA., Nalbant M ve Tekgüler A., 1994. Tane ve Zuruflu Fındıkların Sürtünme Katsayılarının Değişik Yüzeyler için Belirlenmesi. Tarımsal Mekanizasyon 15. Ulusal Kongresi, 20-22 Eylül, Antalya.

Chidananda K., Chelladurai V., Jayas D., Alagusundaram K., White N and Fields P., 2014. Respiration of pulses stored under different storage conditions. Journal of Stored Products Research, 59: 42-47.

De Vincenzi M., Luchetti R., Giovannini C., Pogna NE., Saponaro C., Galterio G and Gasbarrini G., 1996. In vitro toxicity testing of alcohol-soluble proteins from diploid wheat triticum monococcum in celiac disease. Journal of Biochemical and Molecular Toxicology, 11(6): 313-318.

Er C ve Başalma D., 2014. Tohumluk ve Tohumculuk: Temel İlkeler ve Teknoloji. Nobel Akademik Yayıncılık, Ankara.

Fasano A and Catassi C., 2001. Current approaches to diagnosis and treatment of celiac disease: An evolving spectrum. Gastroenterology, 120: 636-651.

Gupta RK and Das SK., 1997. Physical properties of sunflower seeds. Journal of Agricultural Engineering Research, 66(1): 1-8.

Hidalgo A., Brandolin A., Pompei C and Piscozzi R., 2006. Carotenoids and tocols of einkorn wheat (Triticum monococcum ssp. monococcum L.). Journal of Cereal Science, 44: 182-193.

Hidalgo A., Brandolini A and Gazza L., 2008. Influence of steaming treatment on chemical and technological characteristics of einkorn (Triticum monococcum L. ssp. monococcum) wholemeal flour. Food Chemistry, 111: 549-555. 
Kibar, Farklı Nem İçeriklerindeki Siyez Buğdayı Tohumlarının Karbondioksit Değişimleri ve Bazı Mekanik Özelliklerinin Belirlenmesi

Horabik J and Molenda M., 1988. Force and contact area of wheat grain in friction. Journal of Agriculture England Research, 41(1): 32-42.

Huang H., Danao M., Rausch K and Singh V., 2013. Diffusion and production of carbon dioxide in bulk corn at various temperatures and moisture contents. Journal of Stored Products Research, 55: 21-26.

Jain RK and Bal S., 1997. Properties of pearl millet. Journal of Agricultural Engineering Research, 66(1): 85-91.

Jian F., Chelladurai V., Jayas D., Demianyk C and White N., 2014. Interstitial concentrations of carbon dioxide and oxygen in stored canola, soybean, and wheat seeds under various conditions. Journal of Stored Products Research, 57: 63-72.

Kaleta A and Gornicki K., 2013. Criteria of determination of safe grain storage time-a review. Advances in Agrophysical Research (Eds. Grundas S and Stepniewski A), IntechOpen, pp. 295-317.

Karaçalı i., 2009. Bahçe Ürünlerinin Muhafaza ve Pazarlanması. Ege Üniversitesi Ziraat Fakültesi Yayınları No: 494, İzmir.

Kibinza S., Vinel D., Come D., Bailly C and Corbineau F., 2006. Sunflower seed deterioration as related to moisture content during ageing, energy metabolism and active oxygen species scavenging. Physiologia Plantarum, 128: 496-506.

Kutoğlu HY., 1980. Uygulamalı Hidrolik ve Hidroloji. Mesleki ve Teknik Öğretim Kitapları No: 137, Milli Eğitim Basımevi, İsatanbul.

Lawton PJ and Marchant JA., 1980. Direct shear testing of seeds in bulk. Journal of Agricultural Engineering Research, 25(2): 189-201.

Mahjoub M., Movahhed S and Chenarbon HA., 2014. Effective parameters on angle of repose, internal and external friction coefficient in two wheat varieties (Behrang and Shirudi). International Journal of Biosciences, 5(9): 117-124.

Magan N., Sanchis V and Aldred D., 2004. Role of spoilage fungi in seed deterioration. Fungal Biotechnology in Agricultural, Food and Environmental Applications (Eds. Arora DK., Bridge PD and Bhatnagar D), Marcell Dekker, New York, pp. 311-323.

McDonald MB., 1999. Seed deterioration: physiology, repair and assessment. Seed Science and Technology, 27: 177237.

Molenda M., Horabik J and Ross IJ., 1998. Stress and deformation of wheat in direct shear test. International Agrophysics, 12: 115-118.

Molenda M., Montross MD., Horabik J and Ross IJ., 2002. Mechanical properties of corn and soybean meal. Transactions of the ASAE, 45(6): 1929-1936.
Murthy UMN., Kumar PP and Sun WQ., 2003. Mechanisms of seed ageing under different storage conditions for Vigna radiata (L.) Wilczek: lipid peroxidation, sugar hydrolysis, Maillard reactions and their relationship to glass state transition. Journal of Experimental Botany, 54: 10571067.

Pizzuti D., Buda A., D'odorico A., D'inca R., Chiarelli S., Curioni A and Martines, D., 2006. Lack of intestinal mucosal toxicity of Triticum monococcum in celiac disease patients. Scandinavian Journal of Gastroenterology, 41: 1305-1311.

Raudienè E., Rušinskas D., Balčiūnas G., Juodeikienè G and Gailius D., 2017. Carbon dioxide respiration rates in wheat at various temperatures and moisture contents. Mapan, 32(1): 51-58.

Robertson DW., Lute AM and Gardner R., 1939. Effect of relative humidity on viability, moisture content, and respiration of wheat, oats, and barley seed in storage. Journal of Agricultural Research, 59(4): 281-291.

Rusinek R and Stasiak M., 2004. Mechanical Parameters of Agro-Bulk Materials. EU $5^{\text {th }}$ Framework Program, Institute of Agrophysics PAS, Lublin.

Sahoo PK and Srivastava AP., 2002. Physical properties of okra seed. Biosystems Engineering, 83(4): 441-448.

Sollid LM and Khosla C., 2005. Future therapeutic options for celiac disease. Nature Reviews Gastroenterology and Hepatology, 2(3): 140-147.

Throneberry GU and Smith FG., 1955. Relation of respiratory and enzymatic activity to corn seed viability. Plant Physiology, 30: 336-43.

Vaccino P., Becker HA., Brandolini A., Salamini F and Kilian B., 2009. A catalogue of Triticum monococcum genes encoding toxic and immunogenic peptides for celiac disease patients. Molecular Genetics and Genomics, 281: 289-300.

Vincentini O., Maialetti F., Gazza L., Silano M., Dessi M., De Vincenzi $M$ and Pogna NE., 2007. Environmental factors of celiac disease: Cytotoxicity of hulled wheat species Triticum monococcum, T. Turgidum ssp. dicoccum and $T$. aestivum ssp. Spelta. Journal of Gastroenterology and Hepatology, 22: 1816-1822.

Walters C and Engels J., 1998. The effects of storing seeds under extremely dry conditions. Seed Science Research, 8(Supplement): 3-8.

Wieser $H_{.}$, 2001. Comparative investigations of gluten proteins from different wheat species. III. N-terminal amino acid sequences of $\alpha$-gliadins potentially toxic for coeliac patients. European Food Research and Technology, 213: 183-186.

Zou Y and Brusewitz GH., 2001. Angle of internal friction and cohesion of consolidated ground marigold petals. Transactions of the ASAE, 44(5):1255-1259. 